\title{
Zooplanktonic community of six reservoirs in northeast Brazil
}

\author{
Almeida, VLS. ${ }^{\mathrm{a}}$, Dantas, $\hat{E} W^{\mathrm{b}, \mathrm{c}}$, Melo-Júnior, M. ${ }^{\mathrm{d}}$, Bittencourt-Oliveira, MC. ${ }^{\mathrm{e}}$ and Moura, AN. ${ }^{\mathrm{b} *}$ \\ aPrograma de Pós-Graduação em Ecologia e Recursos Naturais, Centro de Ciências Biológicas e da Saúde, \\ Universidade Federal de São Carlos - UFSCar, \\ São Carlos, SP, Brazil \\ bDepartamento de Biologia, Programa de Pós-Graduação em Botânica, \\ Universidade Federal Rural de Pernambuco - UFRPE, \\ CEP 52171-900, Recife, PE, Brazil \\ ${ }^{\circ}$ Centro de Ciências Biológicas e Sociais Aplicadas, \\ Universidade Estadual da Paraíba - UEPB, João Pessoa, PB, Brazil \\ ${ }^{\mathrm{d} D e p a r t a m e n t o ~ d e ~ O c e a n o g r a f i a ~ B i o l o ́ g i c a, ~ I n s t i t u t o ~ O c e a n o g r a ́ f i c o, ~}$ \\ Universidade de São Paulo - USP \\ 'Departamento de Ciências Biológicas, ESALQ, Universidade de São Paulo - USP, \\ Piracicaba, SP, Brazil \\ *e-mail: ariadne@db.ufrpe.br, ariadne_moura@hotmail.com
}

Received July 31, 2007 - Accepted March 12, 2008 - Distributed February 28, 2009

(With 4 figures)

\begin{abstract}
The aim of the present study was to investigate the zooplankton community at six reservoirs in the state of Pernambuco (Brazil). Zooplankton assemblages were identified using current literature and quantitatively analysed under a microscope and stereomicroscope. Concurrently to the sampling of zooplanktonic and phytoplanktonic communities, in situ measurements of abiotic variables, such as water temperature, dissolved oxygen and $\mathrm{pH}$, were determined using field probes and transparency was determined with a Secchi disk. Total phosphorus concentrations were used for the determination of the Trophic State Index. The reservoirs were classified between eutrophic and hypertrophic, oxygenated, with $\mathrm{pH}$ varying from slightly acid to alkaline, high temperatures and low water transparency. A total of 27 zooplankton taxa were identified. Phytoplankton was represented by Cyanophyta, Chlorophyta, Baccilariophyta and phytoflagellates. The highest richness of species was observed for Rotifera (17), followed by Crustacea (8), Protozoa (1) and Insecta (1). Rotifers shared quantitative importance with Crustacea, which were mainly represented by juvenile forms. Jazigo Reservoir presented the highest diversity and equitability. Lowest diversity and equitability were recorded at the Poço da Cruz and Mundaú reservoirs, respectively. Dissimilarity was detected between the environments studied regarding zooplankton composition and structure.
\end{abstract}

Keywords: zooplankton, reservoirs, diversity, Trophic Index State, northeast Brazil.

\section{Comunidade zooplanctônica de seis reservatórios no nordeste do Brasil}

\begin{abstract}
Resumo
O objetivo deste trabalho foi estudar a estrutura e dinâmica do zooplâncton em seis reservatórios do Estado de Pernambuco. A comunidade zooplanctônica foi identificada com literatura atualizada e a densidade analisada sob microscópio e estereomicroscópio. Concomitantemente às coletas das comunidades zooplanctônicas e fitoplanctônicas, foram medidas in situ algumas variáveis abióticas como temperaturas da água e do ar, oxigênio dissolvido, condutividade elétrica, $\mathrm{pH}$, turbidez, usando sondas de campo, transparência com disco de Secchi. As concentrações de fósforo total foram usadas para a determinação do Índice de Estado Trófico. Os reservatórios foram classificados entre eutróficos e hipertróficos, oxigenados, $\mathrm{pH}$ levemente ácido a alcalino, temperaturas altas e baixos valores de transparência da água. O zooplâncton esteve composto por 27 táxons. O fitoplâncton foi representado pelas Cyanophyta, Chlorophyta, Baccilariophyta e Fitoflagelados. A maior riqueza de espécies foi observada para Rotifera, (17), seguida por Crustacea (8), Protozoa (1) e Insecta (1). Rotifera compartilhou a importância quantitativa com os Crustacea, estes representados principalmente pelas formas jovens. No reservatório de Jazigo, foram obtidos os maiores valores para diversidade e equitabilidade. Os valores mais baixos foram registrados em Poço da Cruz e Mundaú, respectivamente. Foi detectada dissimilaridade entre os ambientes estudados quanto à composição e estrutura do zooplâncton.
\end{abstract}

Palavras-chave: zooplâncton, reservatórios, Índice de Estado Trófico, nordeste do Brasil. 


\section{Introduction}

Reservoirs are continental environments considered a transition between lotic and lentic ecosystems. While natural lakes fill up natural depressions, reservoirs normally fill up the valleys of dammed rivers, with differences concerning origin, age, morphology, form, position within hydrographic basins, kinds of use and limnological functioning (Straskraba and Tundisi, 2000). The study of these ecosystems from the ecologic standpoint is needed, as the information may be used in the application of methodological tools for engineering that are capable of minimising the impact of the damming of large rivers (Pinto-Coelho, 1987). Ecological problems reflect in the rapid changes in communities such as zooplankton, which rapidly reorganises the ecosystem and is of great importance in the structure of trophic chains in continental aquatic environments.

The groups Protista, Rotifera and Crustacea are predominant in freshwater zooplankton, the latter of which is mainly represented by Copepoda and Cladocera. Diversity is generally lower in freshwater (Brusca and Brusca, 2002) than in marine environments, as the reduced salinity and the absence of a constant ion concentration expose the organisms to severe ionic and osmotic stress. However, even with low specific density, continental waters generally exhibit considerable zooplankton richness (Dabés, 1995; Nogueira, 2001). Species diversity varies greatly between different water bodies and depends on a complexity of physical, chemical and biological factors (Rocha and Sipaúba-Tavares, 1994). Among these factors, the trophic state greatly influences plankton organisms in continental environments, especially with regard to richness and density (Pinto-Coelho, 1987; Nogueira, 2001).

Freshwater zooplankton has been the focus of a large number of studies. In Brazil, the most studied reservoir ecosystems are located in the Southeast, South and West regions, such as the Paranoá in Brasilia, Pampulha in Minas Gerais, Monte Alegre and Jurumirim in São Paulo and Segredo in Paraná. Many studies have been carried out in these regions on the composition and diversity of zooplankton, especially concerning the Rotifera and Crustacea (Cabianca and Sendacz, 1985; MatsumuraTundisi et al., 1990; Arcifa et al., 1998; Güntzel and Rocha, 1998; Nogueira, 2001; Panarelli et al., 2001; Mitsuka and Henry, 2002).

For the Northeast Region, studies on continental environments are scarce. Brehm and Thomsen (1936), Brehm $(1937 ; 1938)$ and Ahlstrom (1938) were the first to study zooplankton organisms in lentic environments of this region. For four decades, studies in the area were almost nonexistent. There was a renewal in interest in the 1970s with studies by Nordi and Watanabe (1978) on Rotifera of the Epitácio Pessoa Reservoir in the state of Paraíba, and Reid and Turner (1988) on zooplankton of two reservoirs in the state of Maranhão. The first studies on freshwater zooplankton in the state of Pernambuco were carried out by Schubart $(1938 ; 1942)$. Half a century later, research on Pernambuco continental environments were taken up again, with studies by NeumannLeitão and Souza (1987) and Neumann-Leitão et al. (1989), who analysed the zooplankton in the Apipucos Reservoir in the city of Recife, and Bouvy et al. (2001), who analysed the effect of cyanobacteria on the zooplanktonic community in the Ingazeira Reservoir in the Semi-Arid region of the state.

The Northeast Region has a large number of freshwater environments, especially reservoirs constructed to alleviate the pluviometric irregularity of the region and the low water availability in the Semi-Arid. Despite the importance of these environments, little is known regarding their bioecological structure. Thus, the aim of the present study is to analyse the diversity and structure of zooplankton in six water supply reservoirs in the state of Pernambuco, thereby contributing toward broadening the limnological knowledge of the Northeast Region in order to assist future projects of interior water conservation.

\section{Material and Methods}

Six water supply reservoirs located between

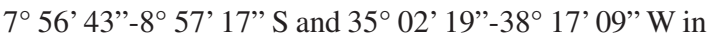
the state of Pernambuco were studied (Table 1, Figure 1). These reservoirs are distributed in the three phyto-geographic regions of the State: 1 . Zona da Mata, with a Köppen climate (pseudotropical hot and wet), strongly influenced by rainfall, with a well-defined wet season (March-August) and dry season (September-February), considered the winter and summer seasons, respectively; 2. Agreste, characterized by a seasonal climate, similar to the Zona da Mata climate, but with lower temperatures and less rainfall; 3 . Sertão, characterized as a semiarid region with an annual mean temperature of $37{ }^{\circ} \mathrm{C}$ and pluviometric irregularities throughout the year, with highest precipitations in March and April. Table 1 displays the location, sample date, water volume and Trophic State Index of the reservoirs studied.

Each reservoir has a characteristic surrounding: Duas Unas Reservoir is located in the Zona da Mata, with sugar-cane plantations and extensive Atlantic rainforest in adjacent areas. There is an expressive presence of aquatic macrophytes along the coastal region of this ecosystem. The Mundaú and Arcoverde Reservoirs are located in the semi-arid region of Pernambuco. Degraded scrublands and open areas are found around these systems, where agriculture activities and cattle-raising are developed. The occurrence of aquatic macrophytes is not expressive in these reservoirs. Scrubland vegetation predominates in the areas where the Poço da Cruz, Jazigo and Saco Reservoirs are located, which also contains areas without vegetation. Aquatic macrophytes are not observed in the region.

Single samples with three repetitions were collected at each reservoir in July, August and November 2004, at 
Table 1. Geographical location, sampling date, water volume and trophic classification of the studied reservoirs (State of Pernambuco, Northeast Brazil).

\begin{tabular}{|c|c|c|c|c|}
\hline \multicolumn{2}{|c|}{ Reservoir } & Latitude & Longitude & Phytogeographical region \\
\hline \multicolumn{2}{|c|}{ Duas Unas } & $8^{\circ} 05^{\prime} 31^{\prime \prime} \mathrm{S}$ & $35^{\circ} 02^{\prime} 19^{\prime \prime} \mathrm{W}$ & Mata \\
\hline \multicolumn{2}{|c|}{ Mundaú } & $8^{\circ} 57^{\prime} 17^{\prime \prime} \mathrm{S}$ & $36^{\circ} 29^{\prime} 55^{\prime \prime} \mathrm{W}$ & Agreste \\
\hline \multicolumn{2}{|c|}{ Arcoverde } & $8^{\circ} 33^{\prime} 33^{\prime \prime} \mathrm{S}$ & $36^{\circ} 59^{\prime} 07^{\prime \prime} \mathrm{W}$ & Agreste \\
\hline \multicolumn{2}{|c|}{ Poço da Cruz } & $8^{\circ} 30^{\prime} 31^{\prime \prime} \mathrm{S}$ & $37^{\circ} 42^{\prime} 17^{\prime \prime} \mathrm{W}$ & Sertão \\
\hline \multicolumn{2}{|c|}{ Jazigo } & $7^{\circ} 59^{\prime} 58^{\prime \prime} \mathrm{S}$ & $38^{\circ} 14^{\prime} 31^{\prime \prime} \mathrm{W}$ & Sertão \\
\hline \multicolumn{2}{|c|}{ Saco } & $7^{\circ} 56^{\prime} 43^{\prime \prime} \mathrm{S}$ & $38^{\circ} 17^{\prime} 09^{\prime \prime} \mathrm{W}$ & Sertão \\
\hline City & Sampling date & Season & Water volume & Trophic State Index \\
\hline Recife & $19 / 08 / 2004$ & Rainy & $28.5 \times 10^{6} \mathrm{~m}^{3}$ & 66.58 - Hypertrophic \\
\hline Garanhuns & $30 / 11 / 2004$ & Dry & $1.9 \times 10^{6} \mathrm{~m}^{3}$ & 63.19 - Hypertrophic \\
\hline Pedra & 20/07/2004 & Rainy & $16.8 \times 10^{6} \mathrm{~m}^{3}$ & 60.59 - Eutrophic \\
\hline Ibimirim & $21 / 07 / 2004$ & Dry & $5.0 \times 10^{8} \mathrm{~m}^{3}$ & 57.82 - Eutrophic \\
\hline Serra Talhada & $22 / 07 / 2004$ & Dry & $15.5 \times 10^{6} \mathrm{~m}^{3}$ & 61.93 - Hypertrophic \\
\hline Serra Talhada & $22 / 07 / 2004$ & Dry & $36.0 \times 10^{6} \mathrm{~m}^{3}$ & 62.91 - Hypertrophic \\
\hline
\end{tabular}

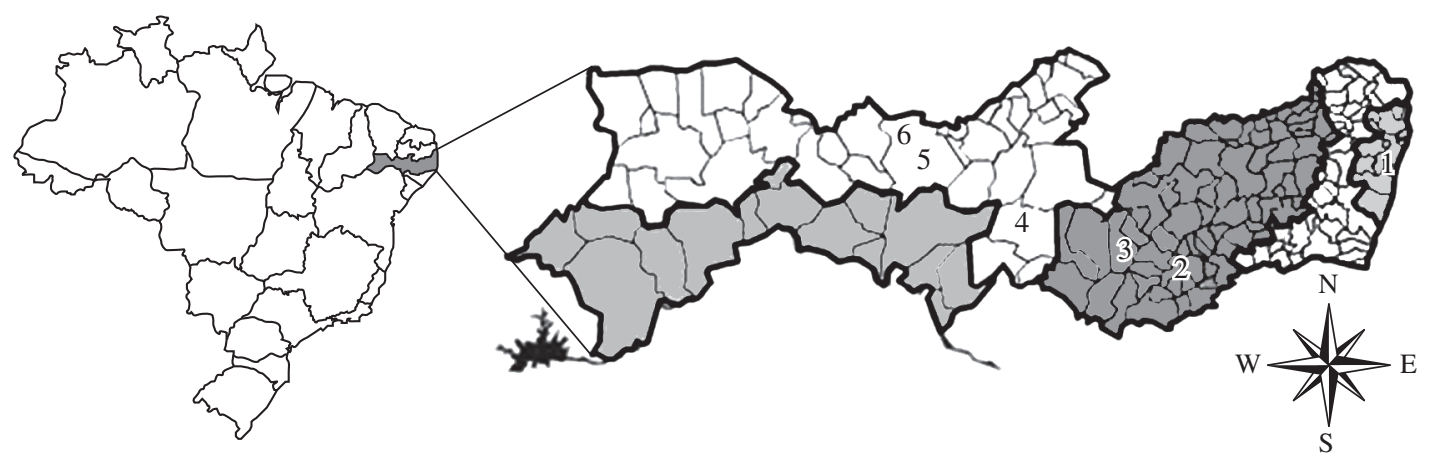

Figure 1. Localization map for the studied areas. Reservoirs: Duas Unas (1), Mundaú (2), Arcoverde (3), Poço da Cruz (4), Jazigo (5) and Saco (6), State of Pernambuco, Northeast Brazil.

a fixed station in the limnetic zone of the bodies of water. All samples were gathered at the surface, using a $40 \mu \mathrm{m}$ mesh plankton net and preserved in $4 \%$ neutralized formaldehyde. The determination of the sample volume was performed according to the formula " $\mathrm{V}_{\mathrm{f}}=\pi \cdot \mathrm{r}^{2} \cdot \mathrm{d}$ ", where " $\mathrm{V}_{\mathrm{f}}$ " is the volume of filtered water; " $\mathrm{r}$ " is the radius of the plankton net mouth; and " $\mathrm{d}$ " is the distance covered (Pinto-Coelho, 2004).

Abiotic variables were also measured: water transparency $(\mathrm{m})$ (using a Secchi disk), water temperature $\left(\mathrm{T}{ }^{\circ} \mathrm{C}\right)$, electrical conductivity $\left(\mu \mathrm{S} . \mathrm{cm}^{-1}\right)$, dissolved oxygen (mg. $\left.\mathrm{L}^{-1}\right)$, turbidity (NUT) and $\mathrm{pH}$ using a Horiba U - 10 field probe and total Phosphorus ( $\mu$ g.PT.L ${ }^{-1}$ ) levels were determined following methods described by Valderrama (1981). The Trophic State Index (TSI) was calculated according to Carlson (1977), using mean values of total phosphorus. The following classification was used: ultra-oligotrophic $(\leq 20)$, oligotrophic (21-40), mesotrophic (41-50), eutrophic (51-60) and hypertrophic ( $\geq 61)$, as proposed by Kratzer and Brezonik (1981). Rainfall and air temperature data for each reservoir were provided by the Instituto Nacional de Meteorologia INMET, for the sampling dates indicated in Table 1.

Aliquots of $100 \mathrm{~mL}$ of water were removed directly from the reservoir and preserved with acetic lugol for the determination of phytoplankton density (ind. $\mathrm{L}^{-1}$ ). It was estimated only on the level of large groups through the sedimentation in chamber method described by Utermöhl (1958), using an inverted Zeiss ${ }^{\circledR}$ microscope, model Axiovert 135M, at 400x magnification. Subsamples of zooplankton were analysed in the laboratory. For Crustacea and Insecta larvae, a $6 \mathrm{~cm}^{2}$ count chamber was used, observed under a Leica stereomicroscope. Rotifera and Protozoa were analysed in a $1 \mathrm{~mL}$ Sedwick-Rafter chamber, under a Leica ${ }^{\circledR}$ ATC 2000 optical microscope. Taxonomical identifications were performed according to Mizuno (1968), Koste (1978), Reid (1985) and Elmoor-Loureiro (1997).

Mean values from the three repetitions of samples at each reservoir were used for the data treatment. Descriptive analysis concerning frequency and relative abundance was performed following procedures de- 
scribed by CETESB (1978). Relative abundance data were used to calculate the Shannon-Wiener specific diversity (H') and Pielou's equitability indexes (1967), using the Diversity software (version 1.2). Cluster analysis was performed to evaluate the similarity between reservoirs regarding the qualitative-quantitative distribution of organisms, using the NTSYS pc 2.1 software. This analysis resulted from a matrix of relative abundance data on the taxa submitted to the WPGMA method, using the Bray-Curtis index.

\section{Results}

Table 2 displays the physical and chemical characteristics. The $\mathrm{pH}$ values were slightly acid to alkaline. Dissolved oxygen varied from 4.50 to $13.01 \mathrm{mg} . \mathrm{L}^{-1}$. Electric conductivity presented a quite heterogenic pattern between environments, with a variation coefficient of 54 percent. In the reservoirs of the Agreste and Sertão, higher electric conductivity was observed in comparison to the Duas Unas Reservoir located in the Zona da Mata, where the collection was performed during the rainy season. Reservoir classification ranged from eutrophic to hypertrophic. Duas Unas in the Zona da Mata and Poço da Cruz in the Sertão exhibited the highest and lowest trophic levels, respectively (Table 2).

The phytoplankton community was represented by Cyanophyta, Bacillariophyta, Chlorophyta and phytoflagellates. Densities per group ranged from $3.73 \times 10^{5}$ ind. $\mathrm{L}^{-1}$ at the Duas Unas Reservoir, to $2.22 \times 10^{7}$ ind. $\mathrm{L}^{-1}$ at the Arcoverde Reservoir. The Duas
Unas Reservoir had a phytoplankton structure formed by phytoflagellates and chlorophytes, whereas the structure of the Poço da Cruz Reservoir was formed by diatomacea. The Mundaú, Arcoverde, Jazigo and Saco Reservoirs had phytoplankton compositions made up of over 60 percent of cyanobacteria (Table 3 ).

The zooplankton community was composed of 27 taxa, distributed among Rotifera, (17), Crustacea (8), Protozoa (1) and Insecta (1) (Table 4). Highest and lowest richness values were observed at Duas Unas and Poço da Cruz Reservoirs, with 16 and 4 taxa, respectively. Rotifera was the group with highest richness (except in the Duas Unas Reservoir, where Crustacea was predominant). Crustacea was mainly represented by nauplius and copepodits.

Most taxa (74.07\%) were considered infrequent, occurring in one or two of the studied environments. The Protozoa Arcella vulgaris, the Rotifera Brachionus falcatus, Keratella tropica, Polyarthra vulgaris, Hexarthra fennica and the Cladocera Moina micrura were frequent, occurring in three or four environments. Only juvenile forms of Crustacea were very frequent, occurring in all or nearly all environments.

Table 4 displays the density values for each taxa. Density between reservoirs ranged from 698 ind.L ${ }^{-1}$ (Saco) to 19701 ind. $L^{-1}$ (Mundaú), with a standard deviation of 8705.31 ind. $\mathrm{L}^{-1}$. Crustacea and Rotifera were both important with regard to quantitative participation among the different reservoirs (Figure 2). Rotifera were more abundant in the Mandaú, Saco and Arcoverde Reservoirs, while Crustacea predominated in Duas Unas

Table 2. Abiotic variables for the studied reservoirs.

\begin{tabular}{lcrrrrr}
\hline \multicolumn{1}{c}{ Abiotic variables } & Duas Unas & Mundaú & Arcoverde & Poço da Cruz & Jazigo & Saco \\
\hline Precipitation $(\mathrm{mm})$ & 138.90 & 200.90 & 205.00 & 68.30 & 68.30 & 68.30 \\
Air Temperature $\left({ }^{\circ} \mathrm{C}\right)$ & 24.00 & 19.30 & 31.70 & 31.70 & 31.70 & 31.70 \\
Electrical Condutivity $\left(\mu \mathrm{S} . \mathrm{cm}^{-1}\right)$ & 32.30 & 345.00 & 300.00 & 160.80 & 289.00 & 420.00 \\
Total phosphorus $\left(\mu \mathrm{g} . \mathrm{L}^{-1}\right)$ & 102.56 & 81.10 & 67.71 & 55.89 & 74.27 & 79.53 \\
Dissolved oxygen $\left({\left.\mathrm{mg} . \mathrm{L}^{-1}\right)}\right.$ & 4.60 & 5.10 & 10.55 & 7.12 & 13.01 & 4.50 \\
pH & 6.28 & 7.40 & 8.84 & 8.28 & 8.68 & 8.06 \\
Water Temperature $\left({ }^{\circ} \mathrm{C}\right)$ & 25.70 & 23.80 & 30.00 & 28.90 & 32.50 & 30.00 \\
Water Transparency $(\mathrm{m})$ & 0.55 & 0.44 & 0.50 & 0.70 & 0.30 & 0.90 \\
Turbidity $(\mathrm{NUT})$ & 37.87 & 13.56 & 37.83 & 8.16 & 25.54 & 6.57 \\
\hline
\end{tabular}

Table 3. Phytoplankton density $\left(10^{5}\right.$ ind. $\left.\mathrm{L}^{-1}\right)$ in the studied reservoirs.

\begin{tabular}{lccccc}
\hline & Cyanophyta & Bacillariophyta & Chlorophyta & Phytoflagellates & Total \\
\hline Duas Unas & 0.00 & 0.25 & 1.65 & 1.83 & 3.73 \\
Mundaú & 94.83 & 0.83 & 5.75 & 7.33 & 108.75 \\
Arcoverde & 159.86 & 8.57 & 1.57 & 52.57 & 222.57 \\
Poço da Cruz & 3.57 & 21.57 & 0.43 & 0.14 & 25.71 \\
Jazigo & 105.29 & 3.00 & 6.29 & 0 & 114.57 \\
Saco & 40.14 & 6.14 & 11.86 & 0.86 & 59.00 \\
\hline
\end{tabular}


Table 4. Zooplanktonic composition, density (ind. $\mathrm{L}^{-1}$ ) and occurrence frequency $(\mathrm{OF})$ in the studied reservoirs. $\mathrm{VF}=$ very frequent; $\mathrm{F}$ = frequent; $\mathrm{FF}$ = few frequent.

\begin{tabular}{|c|c|c|c|c|c|c|c|}
\hline Taxons & 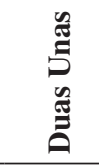 & 莺 & 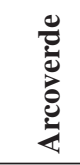 & 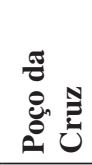 & 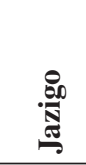 & 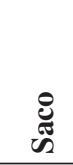 & 瓷 \\
\hline \multicolumn{8}{|l|}{ Protozoa } \\
\hline Arcella vulgaris Ehrenberg, 1830 & - & 750 & 33 & - & 33 & - & $\mathrm{F}$ \\
\hline \multicolumn{8}{|l|}{ Rotifera } \\
\hline Epiphanes macrouros Barrois and Daday, 1894) & - & 100 & - & - & 66 & - & FF \\
\hline Brachionus patulus O. F. Müller, 1786 & - & - & - & 33 & - & - & $\mathrm{FF}$ \\
\hline Brachionus calyciflorus calyciflorus Pallas, 1766 & - & 1700 & - & - & 200 & - & $\mathrm{FF}$ \\
\hline Brachionus angularis Gosse, 1851 & 50 & - & - & - & - & - & FF \\
\hline Brachionus falcatus Zacharias, 1898 & - & 1 & - & - & 166 & 133 & $\mathrm{~F}$ \\
\hline Brachionus havanaensis Rousselet, 1911 & - & - & 33 & - & - & - & $\mathrm{FF}$ \\
\hline Keratella tropica Apstein, 1907 & 50 & 650 & - & 166 & 66 & - & $\mathrm{F}$ \\
\hline Keratella americana Carlin, 1943 & 50 & - & - & - & 33 & - & $\mathrm{FF}$ \\
\hline Lecane curvicornis Murray, 1913 & - & - & 33 & - & - & - & FF \\
\hline Lecane (Monostyla) obtusa Murray, 1913 & - & - & 33 & - & - & - & $\mathrm{FF}$ \\
\hline Lecane (Monostyla) cornuta O. F. Müller, 1786 & 50 & - & - & - & - & - & FF \\
\hline Polyarthra vulgaris Carlin, 1943 & - & 350 & 733 & - & 100 & - & $\mathrm{FF}$ \\
\hline Ploesoma truncatum Levander, 1894 & - & 200 & - & - & - & - & $\mathrm{FF}$ \\
\hline Testudinella sp. & 50 & - & - & - & - & - & $\mathrm{FF}$ \\
\hline Hexarthra fennica Levander, 1892 & 150 & 1200 & - & - & 200 & 333 & $\mathrm{~F}$ \\
\hline Filinia longiseta Ehrenberg, 1834 & 1000 & - & - & - & - & - & $\mathrm{FF}$ \\
\hline Filinia opoliensis Zacharias, 1891 & - & 10500 & 33 & - & - & - & FF \\
\hline \multicolumn{8}{|l|}{ Crustacea Cladocera } \\
\hline Diaphanosoma spinulosum Herbst, 1967 & 800 & - & - & - & - & - & FF \\
\hline Moina micrura Kurz, 1874 & 50 & - & - & - & 33 & 66 & $\mathrm{~F}$ \\
\hline Ceriodaphnia cornuta Sars, 1886 & 5000 & - & - & - & - & - & $\mathrm{FF}$ \\
\hline Daphnia gessneri Herbst, 1967 & 700 & - & - & - & - & - & $\mathrm{FF}$ \\
\hline \multicolumn{8}{|l|}{ Crustacea Copepoda } \\
\hline Notodiaptomus cearensis Wright, 1936 & 300 & 250 & - & - & - & - & $\mathrm{FF}$ \\
\hline Thermocyclops decipiens Kiefer, 1927 & 50 & - & - & - & - & - & $\mathrm{FF}$ \\
\hline Copepodite & 3850 & 500 & 333 & 166 & 100 & - & VF \\
\hline Nauplius & 4300 & 2750 & 466 & 1000 & 733 & 166 & VF \\
\hline \multicolumn{8}{|l|}{ Insecta (larva) } \\
\hline Chaoborus spp. & 50 & 750 & - & - & - & - & FF \\
\hline Total density & 16500 & 19701 & 1697 & 1365 & 1730 & 698 & \\
\hline Richness & 16 & 13 & 8 & 4 & 11 & 4 & \\
\hline
\end{tabular}

(mainly Cladocera), Poço da Cruz and Jazigo Reservoirs (mainly nauplius in the latter two reservoirs).

The most abundant taxa in each reservoir were the Rotifera Filinia opoliensis (53\% in Mundaú), Polyarthra vulgaris (43.2\% in Arcoverde), Hexarthrafennica (47.7\% in Saco), the Crustacea Ceriodaphnia cornuta $(30.2 \%$ in Duas Unas) and nauplius (73.3 and $42.4 \%$ in the de Poço da Cruz and Jazigo Reservoirs, respectively). Diversity ranged from very low ( 0.91 bit.ind $^{-1}$ in Poço da Cruz) to high (3.1 bit.ind ${ }^{-1}$ in Jazigo). Equitability presented val- ues over 0.5 in all reservoirs, with the lowest and highest values observed in the Mundaú (0.55) and Jazigo (0.97) Reservoirs, respectively. Higher equitability values were observed in the reservoirs of the Sertão (Figure 3).

Cluster analysis (Figure 4) revealed dissimilarity between the studied environments. The Mundaú Reservoir exhibited the highest dissimilarity, with correlation level of 0.77. Lowest dissimilarity was evidenced between the Jazigo and Poço da Cruz Reservoirs, with a correlation of 0.48 . 


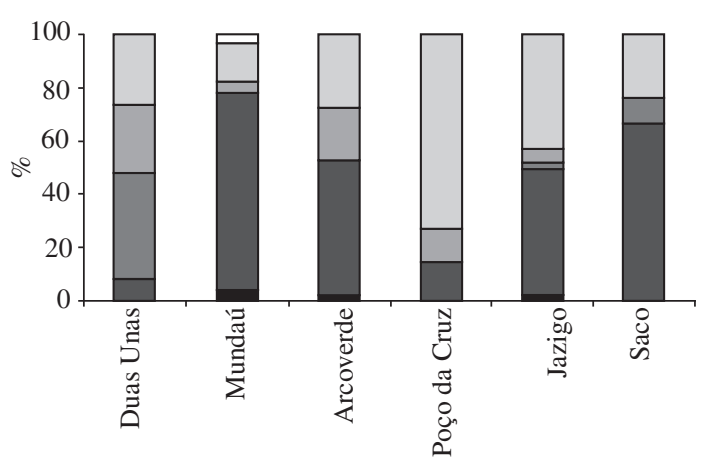

Reservoirs

Protozoa $\square$ Rotifera $\square$ Cladocera

Copepoda $\square$ Nauplius $\square$ Insecta

Figure 2. Relative abundance of the zooplankton groups in the studied reservoirs (for this figure the term "Copepoda" represents only copepodites and adults). $\mathrm{P} . \mathrm{Cruz}=$ Poço da Cruz.

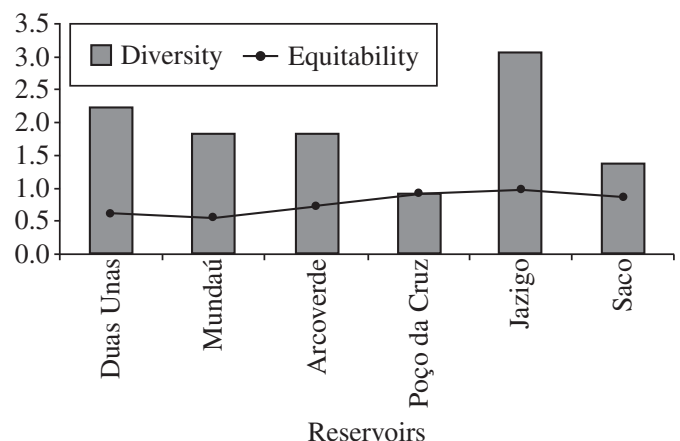

Figure 3. Zooplankton specific diversity and equitability in the studied reservoirs.

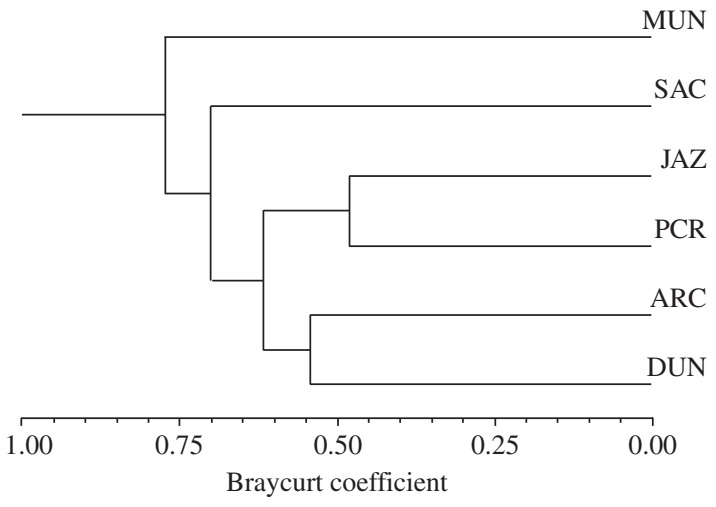

Figure 4. Cluster analysis among the studied reservoirs. Reservoirs: DUN = Duas Unas; MUN = Mundaú; ARC = Arcoverde; $\mathrm{PCR}=$ Poço da Cruz; JAZ = Jazigo; $\mathrm{SAC}=$ Saco.

\section{Discussion}

Rainfall was greater in the reservoirs of the Zona da Mata and Agreste than in the Sertão, with a water shortage in the latter region. Air temperature and consequently, water temperature, was high, confirming the climatic characteristics of Northeast Brazil. Water transparency values were low, reducing the euphotic zone in the reservoirs.

Despite the relatively low values in some reservoirs, dissolved oxygen levels were within the concentrations required by the zooplankton. According to Garcés (1986), threshold conditions for aerobic life are found in environments where values for this parameter are under $4.0 \mathrm{mg} . \mathrm{L}^{-1}$, which was not observed in the studied reservoirs.

The intensity of rainfall associated with evaporation probably had a marked influence on electric conductivity variation between the reservoirs, as observed previously by Bouvy et al. (2000). This variable presented an important influence on zooplankton, as is discussed later on.

The trophic conditions of these environments evidenced the deterioration in water quality. The high input of nutrients is probably due to the expressive presence of monocultures surrounding the reservoirs, especially sugar-cane, which results in the discharge of chemical wastes used in weed control as well as the discharge of sewage and industry wastes, especially in the more urbanized areas (Zona da Mata and Agreste). The higher Trophic State in the Zona da Mata seems to evidence the accumulative pollution effect, as Mundaú Reservoir receives waters from many upstream systems, thereby intensifying local eutrophication.

Specific richness seems to have been directly influenced by the hydrological regime, a fact evidenced by the lower number of taxa observed in the reservoirs in the Sertão, which are generally exposed to an intense hydrological irregularity. A lower richness in reservoirs in the Sertão was also observed by Crispim and Watanabe (2000) in the semi-arid region of the state of Paraíba. Studies have reported low richness and diversity under severe hydrological conditions, such as the long dry periods during the annual cycle. The high richness observed in the Duas Unas Reservoir seems to be contradictory, as it was the most eutrophic ecosystem among the reservoirs studied and according to many authors (eg. Rodríguez and Matsumura-Tundisi, 2000), eutrophication causes a reduction in the number of species. However, Matsumura-Tundisi and Tundisi (2005) found high richness in the eutrophic Barra Bonita Reservoir (state of São Paulo), observing that, contrary to eutrophication processes, horizontal gradients and vertical instability are factors that positively affect plankton richness (intermediate disturbance hypothesis). This could be a general pattern applied to other reservoirs with the same characteristics. According to Esteves (1998), profound alterations in the bodies of water with regard to turbidity, 
flow regimen, food availability, etc., occur during rainy periods and affect the zooplankton community. The pattern observed by Matsumura-Tundisi and Tundisi (2005) for the Barra Bonita Reservoir probably also occurs at the Duas Unas Reservoir, as the sampling was performed during the rainy period.

Pinto-Coelho (1998) found a positive correlation between electric conductivity and Daphnia biomass in the Pampulha Reservoir. However, our study does not corroborate that observation as Duas Unas, which had lower conductivity levels, was the only reservoir with high abundance of Daphnia gessneri. Matsumura-Tundisi and Tundisi (2003) state that calanoid copepods are very sensitive to slight variations in electric conductivity. In the present study, this group was mainly found in reservoirs with intermediate electric conductivity. The increase in conductivity at Mundaú and reduction in conductivity at Duas Unas may have caused the abundance of the group to drop drastically.

Higher richness observed for Rotifera is a common pattern of lentic ecosystems in Brazil (Pinto-Coelho, 1987; Neumann-Leitão et al., 1989; Dabés, 1995; Arcifa et al., 1998; Nogueira, 2001; Sampaio et al., 2002), especially for reservoirs. Rotifers play an important role in the food chains of continental waters (Nordi and Watanabe, 1978; Cabianca and Sendacz, 1985) and are used by many authors as indicators of trophic conditions (Arora, 1966; Pejler, 1983; Neumann-Leitão and Souza, 1987; Berzins and Pejler, 1989; Güntzel and Rocha, 1998; Nogueira, 2001). According to Matsumura-Tundisi (1999), this group generally predominates in reservoirs, as they are r-strategist organisms that rapidly reproduce under hydrodynamic stress conditions, which are common in these systems. The trophic conditions of the studied reservoirs may also be related to the higher richness of Rotifera. According to Rodríguez and MatsumuraTundisi (2000), these organisms are favored by the depletion in water quality.

In general, density in the reservoirs was high in comparison to other continental environments in the state of Pernambuco. In the Jucazinho Reservoir, Melo-Júnior et al. (2007) observed mean Crustacea density values between 832 and 1357 ind. $\mathrm{m}^{-3}$ in both the rainy and dry seasons. In the Apipucos reservoir, Neumann-Leitão et al. (1989) observed zooplankton density values between $11-1386$ ind. $\mathrm{m}^{-3}$ in the annual hydrologic cycle. The Jucazinho and Apipucos reservoirs were considered oligotrophic and eutrophic in these studies, respectively. The high density of zooplankton in the present study may be related to their trophic conditions, as the eutrophication process in water bodies can greatly influence the zooplankton community and is generally associated to an increase in the density of opportunist organisms, such as rotifers and juvenile crustaceans. According to Rocha et al. (1995), zooplankton organisms in natural lakes with different trophic conditions have considerable differences in structure and levels of biomass. Pinto-Coelho et al. (1999) studied the effect of trophic conditions at different points of the Pampulha Reservoir (Central Brazil) and observed elevations in mean zooplankton and phytoplankton density at the more eutrophic sampling point. The study states that, according to Watson et al. (1997), there is a well-known positive relation between increased nutrients and productivity in lakes.

Rotifera and Copepoda shared quantitative importance, the latter of which is a group of great ecological value to lacustrine systems for having different development stages. Copepoda play an essential role in the energy flow, as a great number of species are herbivorous throughout their development, such as Calanoida, a group that has a higher biomass than other zooplankton groups (Nogueira, 2001). The predominance of juveniles among Crustacea detected in our study has also been observed by other authors. Matsumura-Tundisi et al. (1990) found a great participation of nauplius in the zooplankton of the eutrophic Barra Bonita Reservoir (state of São Paulo). In the Caconde Lake (state of Rio Grande do Sul), nauplius represented 60 percent of zooplankton and 90 percent of Copepoda (Güntzel and Rocha, 1998). Bonecker et al. (2001) reported that an increase of Copepoda in the Corumbá Reservoir (state of Goiás), occurred mainly due to the presence of immature individuals.

The low presence of common species among the six reservoirs, explicit by the high percentage of less frequent organisms, corroborates data found by Crispim and Watanabe (2000), who observed great differences in the specific composition among the studied environments (dams and tributaries along the São Francisco River), with few species common to different environments. Low richness resulted in low diversity in some environments. However, equitability showed a tendency toward equilibrium in the distribution of individuals among the species and this could be considered a good indicator of the actual diversity in the reservoirs studied.

Dissimilarity between the reservoirs studied, as evidenced in the cluster analysis, is explained mainly by the different abiotic characteristics of the ecosystems. The trophic state determined zooplankton abundance in the Mundaú and Duas Unas Reservoirs, while zooplankton abundance in the Arcoverde, Jazigo and Poço da Cruz Reservoirs was influenced by hydrological characteristics, such as higher dissolved oxygen levels and $\mathrm{pH}$ as well as lower phosphorus concentrations. Zooplankton abundance in the Saco Reservoir was influenced by higher water transparency and lower turbidity. Higher pluviometric levels were related to an increase in trophic state and turbidity, suggesting that the amount of organic matter in the studied reservoirs increases with the rain, probably from the contribution of waste runoff from agricultural, industrial and urban activities. This characterises a cultural eutrophication process over the natural eutrophication process in these environments.

The results for the studied reservoirs suggest that the zooplankton was more influenced by particular characteristics of each aquatic system than the general characteristics for each phyto-geographic region. This indicates 
that hydrological factors were more important than the climatic factors. Such a finding was expected for continental ecosystems. The evidence of cultural eutrophication reveals the considerable load of pollution received by water supply reservoirs in Brazil, reflecting a serious ecological, economic and social problem due to the importance of these resources.

Acknowledgements - This research was supported by grants from CNPq (Brazilian Council for Research and Development) to ANM (300612/2005-20) and CTHIDRO (503850-2003-9).

\section{References}

AHLSTROM, EH., 1938. Plankton Rotatoria from Northeast Brazil. Anais da Academia Brasileira de Ciências, vol. 10, no. 1, p. 29-51.

ARCIFA, MS., SILVA, LHS. and SILVA, MHL., 1998. The planktonic community in a tropical Brazilian reservoir: composition, fluctuations and interactions. Revista Brasileira de Biologia $=$ Brazilian Journal of Biology, vol. 58, no. 1, p. 241-254.

ARORA, HC., 1966. Rotifera as indicators of trophic nature of environments. Hydrobiologia, vol. 27, no. 1-2, p. 146-159.

BERZINS, B. and PEJLER, B., 1989. Rotifer occurrence in relations to oxygen content. Hydrobiologia, vol. 183, no. 2, p. $165-172$.

BONECKER, CC., LANSAC-TÔHA, FA., VELHO, LFM. and ROSSA, DC., 2001. The temporal distribution pattern of copepods in Corumbá reservoir, State of Goiás, Brazil. Hydrobiologia, vol. 453/454, no. 1, p. 375-384.

BOUVY, M., FALCÃO, D., MARINHO, M., PAGANO, M. and MOURA, A., 2000. Occurrence of Cylindrospermopsis (Cyanobacteria) in 39 Brazilian tropical reservoirs during the 1998 drought. Aquatic Microbial Ecology, vol. 23, p. 13-27.

BOUVY, M., PAGANO, M. and TROUSSELIER, M., 2001. Effects of a cyanobacterial bloom (Cylindrospermopsis raciborskii) on bacterial and zooplankton communities in Ingazeira reservoir (Northeast, Brazil). Aquatic Microbial Ecology, vol. 25, no. 3, p. 215-227.

BREHM, V., 1937. Brasilianische Cladoceran gesammelt von Dr. O. Schubart. Zweiter Berich. Internationale Revue der gesamten Hydrobiologie und Hydrographie, vol. 35, p. 497-512.

-, 1938. Dritter Bericht über die von Dr. O. Schubart in Brasilien gesammelten Onychura. Zoologischer Anzeiger, vol. 122, p. 94-103.

BREHM, V. and THOMSEN, R., 1936. Brasilianische Phyllopoden Arguliden gesammelt von Hern Dr. O. Schubart. Zoologischer Anzeiger, vol. 116, p. 211-218.

BRUSCA, RC. and BRUSCA, GJ., 2002. Invertebrates. Sunderland: Sinauer Associates, 936p.

CABIANCA, MAA. and SENDACZ, S., 1985. Limnologia do reservatório do Borba (Pindamonhangaba, SP), II: zooplâncton. Boletim do Instituto de Pesca, vol. 12, no. 3, p. 83-95.

CARLSON, RE., 1977. A trophic state index for lakes. Minneapolis: University of Minnesota, Limnological Research Center. 17p. Contribution $\mathrm{N}^{\circ} 141$.
COMPANHIA DE TECNOLOGIA DE SANEAMENTO AMBIENTAL - CETESB, 1978. Determinação do zooplâncton marinho: métodos qualitativos e quantitativos. São Paulo: CETESB. 12p. Normalização técnica L5-301.

CRISPIM, MC. and WATANABE, T., 2000. Caracterização limnológica das bacias doadoras e receptoras de água do rio São Francisco: 1 - Zooplâncton. Acta limnologica Brasiliensia, vol. 12, no. 2, p. 93-103.

DABÉS, MBGS., 1995. Composição e descrição do zooplâncton de 5 (cinco) lagoas marginais do rio São Francisco, Pirapora/ Três Marias/Minas Gerais, Brasil. Revista Brasileira de Biologia = Brazilian Journal of Biology, vol. 55, no. 4, p. 831-845.

ELMOOR-LOUREIRO, LMA., 1997. Manual de identificação de cladóceros límnicos do Brasil. Brasília: Universa. 156p.

ESTEVES, FA., 1998. Fundamentos da Limnologia. Rio de Janeiro: Interciência. 602p.

GARCÉS, BHA., 1986. Estudio preliminar sobre el zooplancton del lago Bayano, Panamá. Revista de Biologia Tropical, vol. 32, no. 1 , p. 17-24.

GÜNTZEL, A. and ROCHA, O., 1998. Relações entre a comunidade zooplanctônica e as condições tróficas da lagoa Caconde Osório, RS, Brasil. Iheringia, Série Zoologica, vol. 84, p. 65-71.

KOSTE, W., 1978. Rotatoria: die Rädertiere Mitteleuropas Ein Bestimmungswerk begrüdet von Max Voigt. Berlin: Gebrüder Borntraeger. 637p.

KRATZER, CR. and BREZONIK, PL., 1981. A Carlson type trophic state index for nitrogen in Florida lakes. Water Resources Bulletin, vol. 17, no. 4, p. 713-714.

MATSUMURA-TUNDISI, T., 1999. Diversidade de zooplâncton em represas do Brasil. In HENRY, R. (Ed.). Ecologia de reservatórios: estrutura, função e aspectos sociais. Botucatu: FUNDBIO; FAPESP. p. 39-54.

MATSUMURA-TUNDISI, T., NEUMANN-LEITÃO, S., AGUENA, LS. and MIYAHARA, J., 1990. Eutrofização da represa de Barra Bonita: estrutura e organização da comunidade de Rotifera. Revista Brasileira de Biologia = Brazilian Journal of Biology, vol. 50, no. 4, p. 923-935.

MATSUMURA-TUNDISI, T. and TUNDISI, JG., 2003. Calanoida (Copepoda) species composition changes in the reservoirs: the experience in South America and Brazilian case studies. Hydrobiologia, vol. 500, p. 231-242.

-, JG., 2005. Plankton richness in a eutrophic reservoir (Barra Bonita reservoir, SP, Brazil). Hydrobiologia, vol. 542, no. 1, p. 367-378.

MELO Jr., MM., ALMEIDA, VLS., PARANAGUÁ, MN. and MOURA, AN., 2007. Crustáceos planctônicos de um reservatório oligotrófico do Nordeste do Brasil. Revista Brasileira de Zoociências, vol. 9, no. 1, p. 19-30.

MITSUKA, PM. and HENRY, R., 2002. The fate of Copepod populations in the Paranapanema river (São Paulo, Brazil), downstream from the Jurumirim dam. Brazilian Archives of Biology and Technology, vol. 45, no. 4, p. 479-490.

MIZUNO, T., 1968. Illustrations of the freshwater plankton of Japan. Higashi Ku: Hoikusha. 351p.

NEUMANN-LEITÃO, S. and SOUZA, FBVA., 1987. Rotíferos (Rotatoria) planctônicos do Açude de Apipucos, Recife - 
Pernambuco (Brasil). Arquivos de Biologia e Tecnologia, vol. 30, no. 3, p. 393-418.

NEUMANN-LEITÃO, S., NOGUEIRA-PARANHOS, JD. and SOUZA, FBVA., 1989. Zooplâncton do Açude de Apipucos, Recife - PE (Brasil). Arquivos de Biologia e Tecnologia, vol. 32, no. 4 , p. $803-821$.

NOGUEIRA, MG., 2001. Zooplankton composition, dominance and abundance as indicators of environmental compartmentalization in Jurumirim reservoir (Paranapanema river), São Paulo, Brazil. Hydrobiologia, vol. 455, no. 1-3, p. 1-18.

NORDI, N. and WATANABE, T., 1978. Nota preliminar sobre os rotíferos (zooplâncton) do açude Epitácio Pessoa, Boqueirão, Paraíba. Revista Nordestina de Biologia, vol. 1, no. 1, p. 31-39.

PANARELLI, EA., NOGUEIRA, MG. and HENRY, R., 2001. Short-term variability of copepod abundance in Jurumirim reservoir, São Paulo, Brazil. Revista Brasileira de Biologia $=$ Brazilian Journal of Biology, vol. 61, no. 4, p. 577-598.

PEJLER, B., 1983. Zooplanktonic indicators of trophy and their food. Hydrobiologia, vol. 101, no. 1-2, p. 111-114.

PIELOU, EC., 1967. Mathematical ecology. New York: Wiley. $385 \mathrm{p}$.

PINTO-COELHO, RM., 1987. Flutuações sazonais e de curta duração na comunidade zooplanctônica do lago Paranoá, Brasília - DF. Revista Brasileira de Biologia = Brazilian Journal of Biology, vol. 47, no. 1-2, p. 17-29.

-, 1998. Effects of eutrophication on seasonal patterns of mesozooplankton in a tropical reservoir: a 4-year study in Pampulha Lake, Brazil. Freshwater Biology, vol. 40, no. 1, p. $159-173$

-, 2004. Métodos de coleta, preservação, contagem e determinação de biomassa em zooplâncton de águas epicontinentais. In BICUDO, CEM. and BICUDO, DC. (Eds.). Amostragem em limnologia. São Carlos: Rima. 351p.

PINTO-COELHO, RM., COELHO, MM., ESPÍRITO-SANTO, MM. and CORNELISSEN, TG., 1999. Efeitos da eutrofização na estrutura da comunidade planctônica da Lagoa da Pampulha, Belo Horizonte, MG. In HENRY, R. (Ed.). Ecologia de reservatórios: estrutura, função e aspectos sociais. Botucatu: FUNDBIO; FAPESP.

REID, JW., 1985. Chave de identificação e lista de referências bibliográficas para as espécies continentais sul-americanas de vida livre da ordem Cyclopoida (Crustacea, Copepoda). Boletim de Zoologia, vol. 9, p. 17-143.
REID, JW. and TURNER, PN., 1988. Planktonic Rotifera, Copepoda and Cladocera from Açú and Viana lakes, State of Maranhão, Brazil. Revista Brasileira de Biologia $=$ Brazilian Journal of Biology, vol. 48, no. 3, p. 485-495.

ROCHA, O. and SIPAÚBA-TAVARES, LH., 1994. Cultivo em larga escala de organismos planctônicos para alimentação de larvas e alevinos de peixes. II - Organismos Zooplanctônicos. Biotemas, vol. 7, no. 1-2, p. 94-109.

ROCHA, O., SENDACZ, S. and MATSUMURA-TUNDISI, T., 1995. Composition, biomass and productivity of zooplankton in natural lakes and reservoirs of Brazil. In MATSUMURATUNDISI, T. (Eds.). Limnology in Brazil. Rio de Janeiro: ABC; SBL.

RODRIGUEZ, MP. and MATSUMUTA-TUNDISI, T., 2000. Variation of density, species composition and dominance of rotifers at a shallow tropical reservoir (Broa reservoir, SP, Brazil) in a short scale time. Revista Brasileira de Biologia = Brazilian Journal of Biology, vol. 60, no. 1, p. 1-9.

SAMPAIO, EV., ROCHA, O., MATSUMURA-TUNDISI, T. and TUNDISI, JG., 2002. Composition and abundance of zooplankton in the limnetic zone of reservoir of the Paranapanema river. Revista Brasileira de Biologia $=$ Brazilian Journal of Biology, vol. 62, no. 3, p. 525-545.

SCHUBART, O., 1938. Considerações sobre as investigações nas águas de Pernambuco. Arquivos Instituto de Pesquisas Agronômicas de Pernambuco, vol. 1, no. 1, p. 26-57.

-, 1942. Fauna do estado de Pernambuco e estados limítrofes: segunda lista. Boletim do Museu Nacional, vol. 14-17, p. 21-64.

STRASKRABA, M. and TUNDISI, JG., 2000. Diretrizes para o gerenciamento de lagos: gerenciamento da qualidade dos lagos. São Carlos: ILEC; IIE. 280p.

UTERMÖHL, H., 1958. Zur vervollkommer der quantitativen phytoplankton methodik. Mitteilung Internationale Vereinigung fuer Theoretische und Amgewandte Limnologie, vol. 9, no. 1, p. 1-38.

VALDERRAMA, GC., 1981. The simultaneous analysis of total nitrogen and total phosphorus in natural waters. Marine Chemical, vol. 10, p. 109-122.

WATSON, SB., MacCAULEY, F. and DOWNING, JA., 1997. Patterns in phytoplankton taxonomic composition across temperate lakes of different nutrients status. Limnology and Oceanography, vol. 42, no. 3, p. 487-495. 